\title{
THE HOLISTIC THERAPY FOR EFFECTIVE SERVICES FOR CHILDREN WITH ADHD IN KINDERGARTENS
}

\author{
Nur Hayati ${ }^{*}$, Suparno ${ }^{2}$ \\ ${ }^{1}$ Early Childhood Education, Universitas Negeri Yogyakarta, Indonesia \\ ${ }^{2}$ Special Education Department, Universitas Negeri Yogyakarta, Indonesia \\ Corresponding author: nurhayati@uny.ac.id*
}

\begin{abstract}
Uncontrolled behavior in children with special needs with ADHD is still a phenomenon because they have not received proper services. Parents and teachers need to find the right way to serve children with ADHD to optimize their potential from an early age. This study aims to determine the pattern of teacher services provided to ADHD children in kindergartens. The service pattern provided to ADHD children can help teachers provide stimulation in accordance with the children's needs. This study was conducted in six kindergartens located in Sleman Regency, Yogyakarta City, and Bantul Regency. The qualitative narrative method was employed in this study. The data of this study were collected through observation of ADHD children in six kindergartens and interviews with teachers. The research subjects were six children, and the data analysis technique used was the qualitative descriptive. The research results are divided into two parts. The first part is regarding the service pattern provided by teachers for children with ADHD with combined presentation (inattention and hyperactivity-impulsivity), predominantly inattentive presentation (inattention) and predominantly hyperactive-impulsive presentation. Meanwhile, the second part describes how the teachers treat children with ADHD while they are among their peers and the implication of holistic therapy given to ADHD children. The types of games given to ADHD children are mostly to practice logic, focus, and patience for example, games requiring gross motor and fine motor skills.
\end{abstract}

Keywords:

early childhood, holistic therapy, ADHD

Article Received: 18 October 2020, Revised: 3 November 2020, Accepted: 24 December 2020

\section{Introduction}

Children at early age development and growth are unique, especially for those with special needs. Many children with special needs in Kindergarten show less self-control behavior when interacting with others. Children with special needs are now starting to get more attention from parents, schools, and the community because they are different from children at their age in terms of behavior (Uzunboylu \& Ozcan, 2019; Baglama, Serttas., \& Demirok, 2017; Bateman \& Bateman, 2014). Support and services provided at early childhood for children with special needs can improve their abilities which then may lead them to have an active role in society. Parents have a vital role in fully accepting children with special needs as who they are and supporting their education (Thomson, 2010).
Early age children with special needs, specifically with ADHD, may face various problems in schools, family life, and social interactions (Hoza, 2007). As many as $80 \%$ of children with ADHD often have problematic relationships with peers in which they often experience rejection. Children with ADHD sometimes find it difficult to make friends and be partners in school activities (Goldstein \& Kennemer, 2009). This problem is unavoidable since children with ADHD are inattentive. This often leads to an assumption that those children are unable to obey the rules in society. Their impulsive and hyperactive behaviors are hated by peers because they are not able to evaluate and control themselves as well as respond appropriately to social cues (Kloo \& Kain, 2016).

ADHD (Attention Deficit Hyperactivity Disorder) is a complex developmental disorder that affects 
self-control resulted in inattention, impulsivity, and hyperactivity (Aram, Bazelet \& Goldman, 2010). ADHD is a disorder that begins in childhood that affects academic development, social adaptability in a family, and social adaptability among peers (Garcia, Grau \& Garces 2015; Cherkasova, et al., 2013). Children with attention deficit and hyperactivity disorder tend to move more than normal children do and cannot control themselves, and as a result, it is difficult for them to interact with other people. The clinical appearance of ADHD can be detected early, from the baby's age. They are very sensitive to sound and light and tend to cry and scream. It is difficult for them to stay quiet, and they have very little sleep because they wake up often. They often experience colic, difficulties to eat or drink both breast milk or bottle milk, unwillingness to be calmed or held, refusal to be loved, excessive saliva, and sometimes they continously ask for a drink, bang their heads, hit their heads, drop the head backward, and are often over-tempered (Judarwanto, 2006; Barkley, 2006). The main problem faced by children with ADHD is a neurological condition where the brain fails and is hampered to control their bodies, thus appearing to be inattentive and making uncontrolled quick movements (Kauffman \& Hallahan, 2011).

Attention or hyperkinetic disorders are psychiatric problems or children's behavior disorders that are mostly found both at school and home. Boys with ADHD are more common that girls. This disorder is commonly identified at the age of three (Garcia, Grau \& Garces, 2015).

Boys tend to show very real hyperactivity or impulsive ADHD, while girls are more likely to be negligent (Hallahan, Kauffman \& Pullen, 2014). If ADHD is treated early, it easier for the children to adjust to the later stages of education. When the children start school, both teachers and peers may accept their conditions. Children with ADHD have a high risk of developing psychiatric disorders with symptoms of antisocial behavior, moods that always indicate anxiety, and drug use in early adulthood (Gordon \& Hinshaw, 2015). Prolonged anxiety causes ADHD children to experience mood swings and difficulty to control themselves, and as a result, they become rebellious (Rinsky \& Hinshaw, 2011). Parents and teachers have a very important role for early age children with ADHD as the children often ask for help from other people because they have growth problems.

Children with special needs are entitled to get the same education as their peers in order to be able to socialize from an early age and increase their confidence (Cook, Klein \& Chen, 2015; Dogan \& Bengisoy, 2017; Rajendran, Reddy \& Reddy, 2017; Sivrikaya \& Yikmis, 2016). Various services for children with special needs, especially for children with ADHD, have been done. However, the best technique to provide services for children with ADHD so that they can grow well and adjust themselves to their environment is in question.

\section{Methodology}

This research employed the narrative qualitative approach. The research subjects were six children from six kindergartens located in some areas in the Special Region of Yogyakarta, Indonesia. The study was conducted in Kindergartens A and E located in Sleman Regency area, in Kindergartens $\mathrm{C}$ and D located in the Yogyakarta City area, and in Kindergartens B and F in the Bantul Regency. The data were collected through observation and interviews. Observations were conducted when children with ADHD got involved in activities at school from the beginning to the end of each class. Interviews were conducted with the class teachers, shadow teachers, kindergarten headmasters, and the kid parents to get information about various activities provided to children with ADHD. The questions were related to learning activities, types of games, eating habits, prayers, and how the children have a rest. Various behaviors of children with special needs were used as data in qualitative research (Bystrova, T., Tokarskaya, L. \& Vukovic, D., B., 4623 
2017). Data descriptions regarding the subjects of this study can be seen in table 1.

Table 1. Data on Research Subject

\begin{tabular}{cccc}
$\begin{array}{c}\text { Nam } \\
\text { e }\end{array}$ & Gender & Age (Year) & School \\
\hline Js & Female & 8 & TPA/Pre-School/KindergartenA \\
\hline As & Male & 4 & Inclusive Pre-School B \\
\hline Jt & Male & 6 & Kindergarten C \\
\hline Df & Male & 6 & Kindergarten D \\
\hline Gn & Male & 4 & Kindergarten E \\
\hline Ak & Male & 5 & Kindergarten F \\
\hline
\end{tabular}

The instruments used in this study were interview and observation guidelines. The collected data were analyzed using the qualitative descriptive method. The data were in the form of interviews, observations about children's activities, ADHD type detection instruments, photos, and videos. Those data were collected and analyzed to get accurate information about ADHD children's activities and behaviors. Then, triangulation on data collected from observations and interviews with kindergarten headmasters, teachers, and parents was done.

\section{Results and Discussion}

This research was conducted to examine the pattern of services provided by teachers to children with ADHD. Based on the service patterns of the six ADHD children, information about teachers' treatment and games suitable for the children is collected. Several patterns of care for children with ADHD are tailored to the type of ADHD as listed in the Diagnostic and Statistical Manual of Mental Disorders, fifth edition (DSM-

5) as listed in Table 2.

\begin{tabular}{ll}
\hline No & \multicolumn{1}{c}{ Tipe } \\
\hline 1. & Combined presentation (Inattention and hyperactivity-impulsivity) \\
\hline 2. & Predominantly inattentive presentation (inattention) \\
\hline 3. & Predominantly hyperactive-impulsive presentation \\
\hline
\end{tabular}

Table 2. Description of the ADHD Type According to DSM -5

The types of ADHD listed in table 2 have several characteristics or criteria that can be used as a reference for services. The criteria for ADHD types of attention such as: a) Often fails to give close attention to details or makes careless mistake; b) often has difficulty sustaining attention in activity; c) often does not seem to listen when spoken to directly; d) often has difficulty organizing tasks and activity; e) often does not follow through on instructions and fails to finish schoolwork; f) often avoids, dislikes or is reluctant to engage in task; g) often loses things necessary for tasks or activities; h) often easily distracted by extraneous stimuli; i) often forgetful in daily activities. Kriteria ADHD tipe hyperactivity and impulsivity such as: a) often fidgets with or taps hands or feet or squirms in seat; b) often leaves seat in situations when remaining seated is expected; c) often runs about or climbs in situations where it is inappropriate; $d$ ) 
often unable to play; e) often talks excessively; f) often has difficulty waiting his or her turn; g) often interrupts or intrudes on others; h) often "on the go" or uncomfortable being still for extended time; i) often blurts out an answer before a question has been completed.

Early childhood with special needs can be categorized in combined presentation type ADHD if they have at least 6 characteristics of all attentions and hyperactive-impulsive types, children with attention-type ADHD if they have at least 6 of the 9 attention characteristics and hyperactive-impulsive type ADHD if they have 6 characteristics of 9 hyperactive-impulsive (American Psychiatric Association, 2013). Based on the types and criteria for ADHD mentioned above, it can be concluded that the types found in children with special needs in Kindergarten 3 in the area studied are as in Table 3.

Table 3. Data on the types of early childhood with ADHD in Sleman Regency, Yogyakarta City and Bantul

Regency

\begin{tabular}{cl}
\hline Name & \multicolumn{1}{c}{ ADHD Type } \\
\hline Js, As, Ak & Combined presentation (Inattention and hyperactivity-impulsivity) \\
\hline Df & Predominantly inattentive presentation (inattention) \\
\hline Jt, Gn & Predominantly hyperactive-impulsive presentation \\
\hline
\end{tabular}

Based on the type of ADHD in table 3 found in the field, it can be seen that the services and therapy provided to early childhood with special needs with ADHD in 6 Kindergartens studied in the Special Region of Yogyakarta include:

1. Literacy and behavioral therapy services. Based on the data shown in Table 1, the pattern of services provided to Js who have combined presentation (intattention and hyperactivity-impulsive) ADHD types is a full assistance by a shadow teacher. Js is under a medical therapy by a pediatrician to control her hyperactivity. Medical therapy is given to children with ADHD to reduce hyperactivity and increase attention (Clemow, D.B. et al., 2015). Teachers at her school.

2. provide her with opportunities to play with her friends although for only a limited time. The time is limited because Js sometimes feel disturbed and eventually hurt her friends by hitting and kicking. Puzzles and Legos are given to $\mathrm{Js}$ to stimulate the concentration ability and control her physical activity. The shadow teacher conveyed that through therapy with games done in a certain amount of time, children's cognitive flexibility may www.psychologyandeducation.net improve, thus they can slowly control themselves.

3. Speech and motor therapy services. Services are provided to As who has combined presentation (intattention and hyperactivityimpulsive) ADHD type. During learning processes, As often lies on the floor, does not pay attention to others' people, and does not talk when asked to say a word. The teacher gives treatment by training to pronounce the names of fruits and vegetables in accordance with the learning theme. When As is able to say three words, the teacher adds more words to be pronounced. Speaking intervention in a non-demanding situation will help children with ADHD learn new vocabularies and train them to pay attention to other people.

4. Motor and music therapy services. A child named Jt has a hyperactive-impulsive ADHD type. He is assisted by 1 shadow teacher at school. Jt is provided with speech therapy as well as gross motor and fine motor therapy. The types of games often given to Jt are ball throwing and catching, pushing cars, and puzzle games. Moreover, Jt plays on a piano keyboard and other fine motor games. Gross 
motor therapy helps children waste their energy so that they will not show rage. Motor therapy is as important as other therapy because it can train children to be more patient in controlling their emotions. This motor therapy is done through some activities, such as coloring, doing beadwork, sewing, etc. Playing the piano keyboard can improve children's musical potential and his emotions to follow to the tune. When Jt feels disturbed by others, the shadow teacher will direct $\mathrm{Jt}$ to refocus on learning activities. Jt's shadow teacher asks him to read picture books when he throws a tantrum and then she hugs him to make him chill. The school provides a special instrument to assess Jt.

5. Cognitive and motor therapy services. The pattern of services provided to Df is similar to that of his peers even though Df has an inattention ADHD type. Only when Df shows aggressive behavior, the teacher will give special treatment by separating Df from his friends. The games given to Df are ballthrowing and fine motor activities such as coloring and writing. Df's ability in writing and coloring is good, but he is not able to complete the tasks given. Cognitive treatment is provided to children with ADHD to improve their thinking skills to be more systematic in doing things. His teacher will move closer to him when asking questions. This trains Df to be attentive to other people.

6. Cognitive and behavioral therapy services. Special treatment for $\mathrm{Gn}$ who has hyperactivity-impulsive presentation ADHD type is shadow teacher assistance. During learning, $\mathrm{Gn}$ is always active, but it is greatly influenced by his mood from home. When Gn goes to school happily, he tends to be easily managed and always eager to work on assignments given by the teacher. As an ADHD child, Gn is a fast learner who is capable of quickly completing assignments. His teacher always gives extra activities to prevent him from disturbing his friends. The teacher gives a few games that he likes, and when his friends do not give him the toys that he likes, he will hug them. Gn is fluent in English, so the teacher asks him to speak in English to motivate him. Speech therapy using a foreign language can improve children's confidence and communication skills.

7. Cognitive therapy service. Due to his special needs, Ak is in a special class of an inclusive school. The service provided for him is in the form of stimulations who has Combined presentation (Inattention and hyperactivityimpulsivity) ADHD type. His teacher often trains Ak to respond to others by inviting him to two-way communication. The teacher often asks him to express his opinion or what he feels. Then, he is asked to do the assignment based on the teacher's instructions, but he is allowed to add anything to stimulate his creativity. Indoor and outdoor games provided to Ak are basically the same as what other children do. By doing so, Ak will be more patient and more controlled in interacting with others.

Based on the results of the study with six research subjects, it can be concluded that there are various types of services provided to ADHD children. The service patterns are adjusted to the children's types of ADHD.

Based on the description of the six ADHD children above, it can be seen that there are several patterns of services provided to early childhood with 3 types of ADHD. The results show that the appropriate services that can be given to early childhood with ADHD are holistic services that include cognitive, literacy, behavioral, and motor therapies. In addition, there are also speech and medical therapy services that are provided to children with certain types of ADHD in accordance with their needs. The findings of services for early childhood with ADHD are shown in Table 4. 
Table 4. Services for Early Childhood with ADHD

\begin{tabular}{|c|c|c|c|}
\hline Name & $\begin{array}{l}\text { Shadow } \\
\text { Teacher }\end{array}$ & Game & Therapy \\
\hline Js & $\begin{array}{l}\text { Always in } \\
\text { place }\end{array}$ & $\begin{array}{l}\text { Puzzle and } \\
\text { Legos }\end{array}$ & Behavioral Therapy \\
\hline As & None & Storybook and flashcard & Literacy Therapy \\
\hline $\mathrm{Ak}$ & In place & Constructive Games & Cognitive Therapy \\
\hline Df & None & $\begin{array}{l}\text { Ball throwing and catching and } \\
\text { coloring }\end{array}$ & $\begin{array}{l}\text { Cognitive and Executive } \\
\text { Function Therapy }\end{array}$ \\
\hline $\mathrm{Jt}$ & $\begin{array}{l}\text { Always in } \\
\text { place }\end{array}$ & $\begin{array}{l}\text { Ball throwing and catching, } \\
\text { puzzle, and piano keyboard }\end{array}$ & Speech and Motor Therapy \\
\hline $\mathrm{Gn}$ & In place & Constructive and Motor Games & Literacy Therapy \\
\hline
\end{tabular}

Cognitive therapy is done through executive functioning and behavioral therapy approaches. Cognitive and behavioral therapies are appropriate for inattentive and impulsive ADHD (Minder, F. Zuberer, A., Brandeis, D. \& Drechsler, R., 2019). Literacy therapy is carried out through speech therapy and games with numbers and letters. This is the appropriate treatment for the inattentive type of ADHD. Motor therapy is done by stimulating gross and fine motor skills to improve children's attention. This therapy is suitable for the hyperactive and impulsive types. Different therapies provided for six research subjects are based on the types of ADHD.

Cognitive therapy is given to children with ADHD with cognitive-behavioral approaches. Through various cognitive skills and abilities, the children are trained to find elements and stimuli from their environment, to learn about roles and understand other people roles, to identify the culture, language, values, and morals of society, to make the connection between a characteristic and function, and to improve their knowledge of the environment especially the skills that might be possessed by children with ADHD (Mohammed, 2016). Cognitive stimulation given to early age children with ADHD will increase academic abilities that are highly needed in children's daily activities (Uzunboylu \& Özcan, 2019). This treatment is expected to slowly train children to become independent.

Another therapy for children with ADHD is executive functioning (EF) therapy. EF therapy is given to train children to plan, respond, use memory, and solve problems (Gordon \& Hinshaw, 2019). This type of therapy can train children to control motor skills, predict social activities with friends so that they are able to inhibit inappropriate responses. Thus, ADHD children with good EF abilities have better prosocial abilities and are accepted by peers (Rinsky \& Hinshaw, 2011). Executive functioning therapy can help ADHD children carry out personal activities in their daily lives, such as wearing clothes, going to the toilet, having meals, reading, and completing tasks given by parents and teachers.

Other interventions that can be given to children with ADHD are cognitive training in the form of attention and cognitive control training. This behavioral therapy is provided to inattentive children. Advanced training for the children is in the form of contingency management behavioral interventions, psychosocial interventions, social skills training, problem-solving interventions, cognitive behavior modification, and parental training (Barke, et al., 2013). Cognitive training can be given to ADHD children with the inattention type. This treatment trains children to 
do activities requiring a little concentration and to solve simple problems without being angry.

ADHD Star is a five stage-treatment program for children with ADHD (Adamou et al., 2016). This service includes: 1) collaboration between a service user and a professional providing services in the form of intense interviews to plan a treatment based on the user needs; 2) assurances that assessment results of interviews can be formulated into broader and holistic multidisciplinary plans and interventions; 3) scaffolding of changes to assess the function of the service and identify whether the next steps are appropriate for the user; 4) an opportunity for a different expert to provide input on the services provided; 5) consideration of appropriate programs as a tool to activate the action and get the expected results (Adamou, et al., 2016).

Children with ADHD prefer to spend time doing activities requiring less attention and less details (Alessandri, 1992). An early introduction of literacy for ADHD children can train them to be more patient in paying attention to something starting from paying attention to writing (Aramaic, Bazelet \& Goldman, 2010). Literacy therapy can develop children's cognitive and language skills so they are better prepared for school.

Children with ADHD knowledge and selfpresentation abilities are often troubled and have distinctive patterns, so there is a need to ask them express their emotions (Kloo \& Kain, 2016). Emotion poured into drama activities, poetry and other creative works have a positive impact on children with ADHD self-control, thereby reducing unpredictable movements.

Continuous behavioral therapy done until the children respond without help proved to be very effective in reducing symptoms in ADHD children (Amalia, 2018). According to some experts, behavioral and motor therapies are suitable for hyperactive and impulsive children (O'Neill, Rajendran \& Helperin, 2012). Children with ADHD excessive energy often leads to harmful actions. Children with this type of ADHD should be provided with many opportunities to show their abilities so that they will be able to communicate with many people and to control themselves. Early intervention with various motor game activities can reduce delays in children's motor development (Vasserman, M., Bender, H.A., \& MacAllister, W.S., 2014).

The data of this study were collected from six research subjects consisting of five boys and one girl. This research proves that three out of four children with ADHD are males (Ragnarsdottir, B., Hannesdottir, D.K., Halldorsson, F. \& Njardvik, U., 2018).

Several efforts need to be made to prevent ADHD in children. Education for parents and prospective parents is proven to be very effective in preventing the possibility of children with ADHD (Daley et al, 2009). Monitoring the development of children from an early age can decrease the number of problems and delays in growth.

\section{Conclusion}

ADHD children who get treatment and therapy from an early age will be easier to adapt to the environment. Early treatment for children with ADHD is needed because the main cause of ADHD is brain damage. The most effective therapies given to children at an early age with ADHD are cognitive, behavioral, literacy, and motor therapies. The order of therapy effectiveness corresponds to the type of ADHD with inattention, hyperactivity, impulsivity symptoms. Therapy for children with ADHD aims to train them to respond to stimuli and control their behaviors so they can interact with other people. Children with ADHD are provided with Legos, puzzles, as well as gross motor and fine motor game activities. Delay in providing treatment for ADHD children can cause juvenile delinquency in adolescence. Because they are difficult to control, children with ADHD may later be prone to involve in drug and alcohol abuse and use. Services for children with ADHD are 
expected to train them to be more creative and able to mingle with society in general.

\section{References}

[1] Alessandri, S.M. (1992). Attention, play, and social behavior in ADHD preschoolers. Journal of Abnormal Child Psychology, 20(3), 289-302. https://doi.org/10.1007/bf00916693

[2] Amalia, R. (2018). Intervensi terhadap anak usia dini yang mengalami gangguan adhd melalui pendekatan kognitif perilaku dan alderian play therapy. Jurnal Obsesi: Jurnal Pendidikan Anak Usia Dini Research \& Learning in Early Childhood Education, 2(1), 27-33.

https://obsesi.or.id/index.php/obsesi/article/vi ew/4

[3] Aram, D., Bazelet, I., and Goldman, H. (2010). Early literacy and parental writing mediation in young children with and without ADHD, European Journal of Special Needs Education, 25(4), 397-412. https://doi.org/10.1080/08856257.2010.51354 8

[4] Baglama, B., Demirok, M. S., \& Serttas, Z. (2017).Examining the relationship between pre-service teachers' perceptions on individual differences and attitudes towards individuals with special needs. Journal of Educational Sciences \& Psychology, 7(2). http://jesp.upg-

ploiesti.ro/index.php?option=com_phocadow nload $\&$ view=categry $\&$ id $=27$ :journal-vol-viilxixno-22017\&Itemid $=16$

[5] Barke, et al. (2013). Nonpharmacological interventions for ADHD: systematic review and meta-analyses of randomized controlled trials of dietary and psychological treatments, AmJ Psychiatry, 170(3), 275-89. https://doi.org/10.1176/appi.ajp.2012.120709 91.

[6] Bateman, D. F., \& Bateman, C. F. (2014). A principal's guide to special education. Council for Exceptional

Children.
https://files.eric.ed.gov/fulltext/ED455624.pd $\mathrm{f}$

[7] Bystrova, T., Tokarskaya, L., Vukovic, D.,B. (2017). Visual perception specifics of children with ASD as a determinant for educational environment outline times. International Journal Of Cognitive Research In Science, Engineering, and Education $\begin{array}{llll}\text { (IJCRSEE) } & 5 & \text { (1), }\end{array}$ https://doi.org/10.5937/IJCRSEE1701075B

[8] Cook, R. E., Klein, M. D., \& Chen, D. (2015). Adapting early childhood curricula for children with special needs. Pearson. https://scholarcommons.cu.edu/faculty_books 19/

[9] Daley, D., Jones, K., Hutchings, J., \& Thompson, M. (2009). Attention deficit hyperactivity disorder in pre-school children: Current findings, recommended interventions and future directions. Child: Care, Health and Development, 35, 754-766. https://doi.org/10.1111/j.13652214.2009.0093 8.x

[10] García, J.V.,Grau, C \& Garcés, J. (2015). Learning and behaviour of three- to five-yearold children with ADHD. Journal for the Study of Education and Development, 38(4), 775-807.

https://doi.org/10.1080/02103702.2015.10762 68

[11] Goldstein, S., \& Kennemer, K. (2009). Neuropsychological aspects of attentiondeficit hyperactivity disorder. In C. R. Reynolds \& E. Fletcher-Janzen (Eds.), Handbook of Clinical Child neuropsychology (3rd ed., 617-634). New York, NY: Springer.

[12] Gordon, C.T., and Hinshaw, S. P. (2015). Parenting stress as a mediator between childhood ADHD and early adult female outcomes, Journal of Clinical Child \& Adolescent Psychology, 0(0), 1-12. https://doi.org/10.1080/15374416.2015.10415 95 
[13] Hallahan, Kauffman dan Pullen. (2014). Exceptional Learners An Introduction To Special Education Twelfth Edition, London: Pearson Education Limited.

[14] Cherkasova, M., Sulla, E., Dalena, K., Pondé, M., \& Hechtman, L. (2013). Developmental course of attention deficit hyperactivity disorder and its predictors. Journal Canadian Academy of Child \& Adolescent Psychiatry, 22 , 47-54. https://psycnet.apa.org/record/2013-02970007

[15] Hoza, B. (2007). Peer functioning in children with ADHD. Journal of Pediatric Psychology, 32 , 655-663. https://doi.org/10.1093/jpepsy/jsm024

[16] Kauffman, J.M. dan Hallahan, D.P (2011). Handbook of Special Education, New York dan London: Routledge Taylor \& Francis Group.

[17] Kloo, D. \& Kain, W. (2016). The direct way may not be the best way: Children with ADHD and their understanding of selfpresentation in social interactions, European Journal of Developmental Psychology, 13(1), 40-51.

https://doi.org/10.1080/17405629.2015.10519 60

[18] Minder, F. Zuberer, A., Brandeis, D. \& Drechsler, R. (2019). Specific Effects of Individualized Cognitive Training in Children with Attention-Deficit/Hyperactivity Disorder (ADHD): The Role of Pre-Training Cognitive Impairment and IndividualTraining Performance, Developmental Neurorehabilitation, 22 (6), 400-414. https://doi.org/10.1080/17518423.2019.16000 64

[19] Mohammed, Ali Mohammed Haidar. (2016). The Cognitive Abilities and Skills of Children Who Suffer from Attention Deficit and Hyperactivity Disorder (ADHD) in Kuwait State. Journal of Education and Practice.
7(17),

149-155.

https://eric.ed.gov/?id=EJ1108659

[20] O’Neill, S., Rajendran, K., Halperin, J.M. (2012). More than child's play: the potential benefits of play-based interventions for young children with ADHD. Expert Review of Neurotherapeutic, 12 (10), 1165-1167. https://doi.org/10.1586/ern.12.106

[21] Ragnarsdottir, B., Hannesdottir, D. K., Halldorsson, F., \& Njardvik, U. (2018). Gender and Age Differences in Social Skills Among Children with ADHD: Peer Problems and Prosocial Behavior. Child \& Family Behavior Therapy, 40 (4), 263-278. https://doi.org/10.1080/07317107.2018.15221 52

[22] Rajendran, V., Venkatagari, S., \& Manchireddy, S. (2017). Teaching and Learning Methodologies for Improving Students' Performance in Academics. International Journal of Learning and Teaching, $\quad 9(4), \quad$ 437-444. https://doi.org/10.18844/ijlt.v9i4.1843

[23] Rief, S.F. (2008). The ADD/ADHD Checklist a practical reference for parents \& teachers, second edition. United State of America: Jossey-Bass.

[24]Rinsky, J.R \& Hinshaw, S.P. (2011). Linkages between childhood executive functioning and adolescent social functioning and psychopathology in girls with ADHD, Child Neuropsychology: A Journal on Normal and Abnormal Development in Childhood and Adolescence, 17(4), 368-390. https://doi.org/10.1080/09297049.2010.54464 9

[25] Sivrikaya, T., \& Yikmis, A. (2016). Özel egitim siniflarinda görev yapan özel egitim mezunu olan ve olmayan ögretmenlerin ögretim süreciyleilgili gereksinimleri (The instructional process requirements of special education graduate and non-graduate teachers working in special education classes). Abant Izzet Baysal Üniversitesi Egitim Fakültesi 
Dergisi, 16(4), 1984-2001. https://dergipark.org.tr/download/articlefile/2 91954

[26] Uzunboylu, H. \& Özcan, D. (2019). Teaching methods used in special education: A content analysis study. International Journal of Cognitive Research in Science, Engineering, and Education (IJCRSEE), 7(2). https://doi.org/10.5937/IJCRSEE1902099U

[27] Vasserman, M., Bender, H.A., \& MacAllister, W.S. (2014) Motor Skills Development in Children With Inattentive Versus Combined Subtypes of ADHD. Applied Neuropsychology: Child, 3(2), 145-151, https://doi.org/10.1080/21622965.2012.75946 